\title{
Flavonoid Composition and Biological Activities of Ethanol Extracts of Caryocar coriaceum Wittm., a Native Plant from Caatinga Biome
}

\author{
Daniela Ribeiro Alves, ${ }^{1}$ Selene Maia de Morais, ${ }^{1}$ Fernanda Tomiotto-Pellissier, ${ }^{2}$ \\ Milena Menegazzo Miranda-Sapla, ${ }^{2}$ Fábio Roger Vasconcelos, ${ }^{3}$ Isaac Neto Goes da Silva, ${ }^{1}$ \\ Halisson Araujo de Sousa, ${ }^{4}$ João Paulo Assolini, ${ }^{2}$ Ivete Conchon-Costa, ${ }^{2}$ \\ Wander Rogério Pavanelli, ${ }^{2}$ and Francisco das Chagas Oliveira Freire ${ }^{3}$ \\ ${ }^{1}$ Veterinarian Sciences Post Graduation Program, Ceará State University, Av. Dr. Silas Munguba 1700, Campus do Itaperi, \\ 60714-903 Fortaleza, CE, Brazil \\ ${ }^{2}$ Pathological Sciences Center, Londrina State University, Rodovia Celso Garcia Cid, PR 445, Km 380, Campus Universitário, \\ 86057-970 Londrina, PR, Brazil \\ ${ }^{3}$ Embrapa Agroindústria Tropical, Rua Dra. Sara Mesquita 2270, Planalto do Pici, 60511-110 Fortaleza, CE, Brazil \\ ${ }^{4}$ Chemical Course, Ceará State University, Av. Dr. Silas Munguba 1700, Campus do Itaperi, 60714-903 Fortaleza, CE, Brazil
}

Correspondence should be addressed to Selene Maia de Morais; selene.morais@uece.br

Received 29 April 2017; Accepted 24 July 2017; Published 7 September 2017

Academic Editor: Lucindo Quintans

Copyright (C) 2017 Daniela Ribeiro Alves et al. This is an open access article distributed under the Creative Commons Attribution License, which permits unrestricted use, distribution, and reproduction in any medium, provided the original work is properly cited.

\begin{abstract}
Caryocar coriaceum fruits, found in Brazilian Cerrado and Caatinga, are commonly used as food and in folk medicine, as antiinflammatory, bactericide, fungicide, leishmanicide, and nematicide. Due to the biological potential of this plant, this study focuses on the evaluation of antifungal and antileishmanial activities, including anticholinesterase and antioxidant tests, correlating with total phenols and flavonoids content. Peel extracts contain higher yield of phenols and flavonoids as analyzed by spectrophotometric methods. HPLC analysis of flavonoids revealed that isoquercitrin is the main flavonoid in both parts of the fruit, and peel extract showed the best antioxidant activity. In the inhibition of the acetylcholinesterase assay, both extracts demonstrate action comparable to physostigmine. The antimicrobial activity of extracts was evaluated against strains of Malassezia sp. and Microsporum canis, using the broth microdilution technique, in which the extracts showed similar MIC and MFC. The extracts present antileishmanial activity and low toxicity on murine macrophages and erythrocytes. Therefore, these results suggest a potential for the application of C. coriaceum fruit's ethanol extracts in the treatment against dermatophyte fungi and leishmaniasis, probably due to the presence of active flavonoids. Further in vivo studies are recommended aiming at the development of possible new pharmaceutical compounds.
\end{abstract}

\section{Introduction}

In veterinary care, some diseases are common in Brazil as fungal dermatophytosis and cutaneous/mucocutaneous leishmaniasis. Regarding fungal diseases, Malassezia, Microsporum, and Trichophyton genera are the main infectious agents of human and animal cutaneous mycoses $[1,2]$.

Leishmaniases are zoonosis caused by protozoa of the Leishmania genus with a wide range of clinical symptoms: cutaneous, mucocutaneous, and visceral [3]. In these parasitic diseases, humans and wild, synanthropic, and domestic mammals act as hosts and/or reservoirs of several Leishmania spp. [4].

Cutaneous/mucocutaneous leishmaniasis is usually characterized by chronic skin lesions and permanent scars with deformation of the infected area [5]. This disease presented more than 1 million cases reported in the last five years, with over 431 million people living in endemic areas at risk 
of infection [3]. Leishmania spp. are pathogens that infect mainly macrophages, but also neutrophils and dendritic cells. The parasites are able to evade the microbicidal mechanism of these cells resulting in the different forms of disease, according to the Leishmania species [6-8].

Although both diseases present therapeutic options such as the azoderivatives for fungal treatment, especially ketoconazole and itraconazole and pentavalent antimonial drugs for leishmaniasis chemotherapy, these drugs present low efficacy and severe side effects as cardiotoxicity and hepatotoxicity [5]. Thus, many researchers have been trying to find safer plant-derived natural products to treat these diseases $[6,7,9,10]$.

The Caryocar genus, known popularly as Pequi, has a wide distribution and is represented in several Brazilian biomes such as Cerrado, the Atlantic Forest, Amazon, and Caatinga [11, 12]. The fruit pulp is largely used in food preparation, mainly with rice. The fruit pulp and seed oils of Caryocar coriaceum have been used in wound healing, as an anti-inflammatory agent, and for the treatment of diseases of the respiratory tract, including cough, bronchial affections, and asthma The fruit crude oil is also used on small skin wounds, in the form of compresses and massage, for treatment of rheumatic and muscular pains [13].

The Caryocar species is considered a promising medicinal product due to its bactericidal, fungicidal, leishmanicidal, and nematicidal activities $[14,15]$. In this work, ethanol extracts of pulp and peel of C. coriaceum fruits were evaluated in relation to phenols and flavonoids content and biological activities such as antifungal and antileishmanial activities using different microorganisms from the previous work. Thus, in this study, dermatophyte fungi and Leishmania amazonensis parasites were used and the antioxidant and antiacetylcholinesterase activities were investigated, which support their antileishmanial and antifungal properties.

\section{Materials and Methods}

2.1. Chemicals. 2,2-Diphenyl-1-picrylhydrazyl (DPPH), 5,5'dithiobis(2-nitrobenzoic acid) (DTNB), acetylthiocholine iodide (ATCI), and other reagents were acquired from Sigma Chemical Co. (St. Louis, MO, USA). Quercetin, isoquercitrin, and rutin were obtained from the seeds of the plant Dimorphandra gardneriana according to a previous report [16].

2.2. Preparation of Plant Extracts. Peel and pulp of C. coriaceum mature fruits were obtained at the Campus of the Ceará State University (lat.: -3.792222; long.: -38.556111), Fortaleza, Brazil. These C. coriaceum plants were submitted and identified by Prisco Bezerra Herbarium under the code EAC57060. The extracts were obtained by cold maceration with $96 \%$ ethanol, at $12 \mathrm{~h}$ cycle of light, without agitation for 7 days. Filtration of the supernatant and evaporation of the solvent at reduced pressure in a rotary evaporator led to crude ethanol extracts of Pequi fruit pulp and fruit peel.

2.3. Qualitative Determination of Chemical Constituents. The presence of secondary metabolites was detected by visual observation of color changes or precipitate formation reactions [17]. The reactions were conducted by the $\mathrm{pH}$ variation of ethanol extracts (with sodium hydroxide and sulfuric acid) to detect the presence of flavonols, flavanones, flavanonols, anthocyanins, and catechins; Lieberman-Burchard reagent (acetic anhydride plus sulfuric acid) is used for steroids (green color) or triterpenes (red color) characterization. Ferric chloride solution was used to detect phenols and tannins, and Shinoda reagent (concentrated $\mathrm{HCl}$ and granulated magnesium ribbon) was used to detect flavonoids and xanthones (a pink to red color); when shaking the dry extract with distilled water, if permanent foam is formed, this characterizes the presence of saponins.

2.4. Quantitative Determination of Total Phenol Content. Total phenol content was quantitatively determined using Folin-Ciocalteu's method [18]. The absorbance was measured at $750 \mathrm{~nm}$ using a UV/Vis spectrophotometer. The blue color indicated the presence of phenol content. The results are expressed in $\mathrm{mg}$ of gallic acid equivalent per gram of extract (mg GAE/g) based on a linear equation for a standard curve prepared with gallic acid.

2.5. Quantitative Determination of Total Flavonoid Content. The flavonoid content was determined using Funari and Ferro's method [19]. The absorbance was measured at $425 \mathrm{~nm}$. Yellow color indicated the presence of flavonoids. The flavonoid content is expressed in $\mathrm{mg}$ of quercetin equivalent per gram of extract ( $\mathrm{mg} E Q / \mathrm{g})$, on a linear equation for a standard curve prepared with quercetin.

2.6. Characterization of Flavonoids by HPLC. The identification and quantification of flavonoids on EEPUCC and EEPECC were performed by high-performance liquid chromatography (HPLC) with Shimadzu liquid chromatograph coupled to an SCL-10AVP controller system, UV-Vis detector SPD-10AVP, and isocratic pump LC-10ATVP. The LC Solution software was used to record the chromatograms and measure peak areas. The column used was a Shimadzu analytical CLC-ODS M (C-18) of $25 \mathrm{~cm}$. The calibration curve was constructed using the standards rutin, isoquercitrin, and quercetin, injected at different concentrations $(0.25,0.05$, 0.025 , and $0.005 \mathrm{mg} / \mathrm{mL}$ ) into the liquid chromatograph. The flow rate was $1.8 \mathrm{~mL}$ per minute for quercetin and $1.25 \mathrm{~mL}$ per minute for rutin at a wavelength of $350 \mathrm{~nm}$ a mobile phase composed of acetonitrile and $\mathrm{H}_{3} \mathrm{PO}_{4}$ buffer at $\mathrm{pH} 2.8(20 \%: 80 \%)$. The linear regression equation was obtained by using the Microsoft Office Excel 2010 program. The chromatographic profiles of flavonoids rutin, quercetin, and isoquercitrin, the chosen standards, were obtained by preparing ethanol solutions at a concentration of $0.5 \mathrm{mg} / \mathrm{mL}$ and then injecting them into the high-performance liquid chromatograph. As the mobile phase, the same solution was used for calibration curve at the same wavelength and flow rate of $1.80 \mathrm{~mL}$ per minute.

2.7. Assessment of Antioxidant Activity via 2,2-Diphenyl-1picrylhydrazyl (DPPH) Radical Reduction. Antioxidant activity of EEPUCC and EEPECC was assessed using a previously 
described method [20], with some modifications. Several dilutions of the samples and positive control (rutin) in methanol were prepared to obtain the concentrations of 100 , 50,5 , and $1 \mu \mathrm{g} / \mathrm{mL}$. Methanol was used as a negative control. The absorbances were measured at $515 \mathrm{~nm}$ using a UV-Vis spectrophotometer. The percentage inhibition (PI) was calculated according to the following equation: $\mathrm{PI} \%=[$ (absorbance of DPPH - absorbance of the extract)/absorbance of DPPH] $\times 100$. The $\mathrm{IC}_{50}$ values were determined by linear regression of the plotted data followed by Tukey's test for multiple comparisons.

2.8. Inhibition of Acetylcholinesterase (AChE) Enzyme. The AChE inhibitory activity was qualitatively assessed using Ellman's [21] methodology, adapted for thin layer chromatography by Rhee et al. [22]. Solutions of the fruit pulp and peel at the concentration of $2.0 \mathrm{mg} / \mathrm{mL}$ were applied to TLC aluminum chromatoplate silica gel 60 F254 (Merck $\left.{ }^{\circledR}\right)$ forming $2 \mathrm{~mm}$ spots. The plate was sprayed with $5,5^{\prime}$-dithiobis(2nitrobenzoic acid) (DTNB)/acetylthiocholine iodide (ATCI) reagent $(1 \mathrm{mM}$ DTNB and $1 \mathrm{mM}$ ATCI in $50 \mathrm{mM}$ Tris- $\mathrm{HCl}$, $\mathrm{pH} 8$ ) until the silica was carefully saturated with the solvent. Plates were allowed to dry and then $5 \mathrm{U} / \mathrm{mL}$ of AChE enzyme solution was sprayed. A yellow background was observed, with white zones, indicating the presence of AChE enzyme inhibiting compounds. These zones became visible after $5 \mathrm{~min}$. The zones were observed, measured, and recorded. Physostigmine was used as standard.

2.9. Fungicidal Assay. The minimum concentration capable of inhibiting $100 \%$ fungi growth (MIC) was determined by the dilution technique, according to CLSI method [23]. Six strains were tested (3 Malassezia spp.: MA239, MA276, and MA355; 3 Microsporum canis: MC017/15, MC029/15, and $\mathrm{MC115} / 15)$, isolated from infected domestic animals, identified and stocked at the Microbiology Section, and kindly donated by Vettings ${ }^{\circledast}$. The spore suspension solution for initial inoculation was prepared from filamentous fungi cultivated on potato dextrose agar (PDA) and incubated at a temperature of $28 \pm 2^{\circ} \mathrm{C}$ for 7 days. The spore count was performed in a Neubauer chamber to achieve the concentration of $10^{5}$ to $10^{6}$ cells. In laminar flow cabinet, $100.0 \mu \mathrm{L}$ of the RPMI medium was distributed into each well of a 96well microplate. $100.0 \mu \mathrm{L}$ of EEPUCC and EEPECC extracts was added and serial dilution was performed from 2500.0 to $2.44 \mu \mathrm{g} / \mathrm{mL}$. Finally, $50.0 \mu \mathrm{L}$ of the fungal suspension was added to all wells except the lines intended for the control of the sterile medium. The readings were taken by checking the MIC, with the aid of stereoscopically checking the lowest concentration of the samples capable of inhibiting $100 \%$ of the growth of the microorganism, after 5 days of incubation. The plates were also inspected under an inverted microscope to ensure growth of the controls and sterile conditions. The minimal fungicide concentration (MFC), considered as the minimum concentration capable of killing $100 \%$ of fungi, was measured by transferring $50.0 \mu \mathrm{L}$ from wells without fungal growth and inoculating on PDA. MFC was established according to the fungus growth after incubation under the same conditions for 5 days.

2.10. Leishmania Parasite. Leishmania (Leishmania) amazonensis (MHOM/BR/1989/166MJO) was used in promastigote forms, in the stationary growth phase (day 5 of culture). The parasites were obtained from popliteal lymph nodes of $L$. amazonensis-infected $\mathrm{BALB} / \mathrm{c}$ mice and maintained in 199 culture medium (Gibco) supplemented with $10 \%$ fetal bovine serum (FBS) (Gibco), $10 \mathrm{mM}$ HEPES Biological Buffer (AMRESCO), 0.1\% human urine, 0.1\% L-glutamine (SYNTH), penicillin $(10 \mathrm{U} / \mathrm{mL})$ and streptomycin $(10 \mu \mathrm{g} / \mathrm{mL})$ (Gibco), and 10\% sodium bicarbonate (SYNTH). Cell cultures were incubated at $25^{\circ} \mathrm{C}$ in $25 \mathrm{~cm}^{2}$ flasks. All parasites were from a culture that was serially passed for less than 5 weeks.

2.11. Viability of L. amazonensis Promastigote Forms. The direct effect of EEPUCC and EEPECC extracts against $L$. amazonensis was assessed in 24-well microtiter plates, each well containing $1000 \mu \mathrm{L}$ of 199 supplemented culture medium with $1 \times 10^{6}$ promastigote forms in stationary phase with or without the extracts of interest at final concentrations of 0.1 , 0.05 , and $0.025 \mathrm{mg} / \mathrm{mL}$. Viable promastigote concentration was determined by Neubauer chamber counting after 24, 48 , and $72 \mathrm{~h}$ of treatment. In the stock solutions of extracts, $0.01 \%$ dimethyl sulfoxide (DMSO) (Gibco) was used as vehicle. Untreated parasites and vehicle only (0.01\% DMSO) were included as negative controls. The plates were also inspected under an inverted microscope to ensure growth of the controls and sterile conditions. The 50\% inhibitory concentration $\left(\mathrm{IC}_{50}\right)$ was determined by nonlinear regression analysis of the obtained data.

2.12. Animals. $\mathrm{BALB} / \mathrm{c}$ mice weighing approximately $25-30 \mathrm{~g}$ and aged 6-8 weeks were used, according to protocols approved by the ethics committee of Londrina State University, which approved the protocol for animal use (13134.2016.62).

2.13. Peritoneal Macrophages Viability Assay. The viability of peritoneal macrophages treated with EEPUCC and EEPECC extracts was evaluated using the 3-(4,5-dimethylthiazol-2yl)-2,5-diphenyltetrazolium bromide (MTT) assay as previously described by Mosmann [24]. BALB/c peritoneal macrophages $\left(5 \times 10^{5} \mathrm{U} / \mathrm{mL}\right)$ were cultured in 24-well plates with $500 \mu \mathrm{L}$ of 199 medium for $2 \mathrm{~h}$ for adherence at $37^{\circ} \mathrm{C}$ and $5 \% \mathrm{CO}_{2}$. The cells were washed with PBS and then adherent cells were incubated with different concentrations of extracts $(2.5-0.025 \mathrm{mg} / \mathrm{mL})$ or with vehicle $(0.1 \%$ DMSO) and maintained in culture for $24 \mathrm{~h}$ at $37^{\circ} \mathrm{C}$ and $5 \% \mathrm{CO}_{2}$. After incubation with extracts, the macrophages were washed with PBS and MTT was added at a final concentration of $5 \mu \mathrm{g} / \mathrm{mL}$ in each well, followed by incubation for $4 \mathrm{~h}$ at $37^{\circ} \mathrm{C} / 5 \% \mathrm{CO}_{2}$. The MTT formazan product was solubilized with $300 \mu \mathrm{L}$ of DMSO, and plates were read at $570 \mathrm{~nm}$ in a spectrophotometer. The $50 \%$ cytotoxicity concentration 
$\left(\mathrm{CC}_{50}\right)$ was determined by nonlinear regression analysis of the obtained data.

2.14. Selectivity Index (SI). The degree of selectivity of EEPUCC and EEPECC extracts was expressed as $\mathrm{SI}=\mathrm{IC}_{50}$ of extracts on macrophages/ $\mathrm{IC}_{50}$ of the same extract on promastigotes.

2.15. Hemolytic Assay. Blood from healthy subjects was collected in a heparinized vacuum tube, and the erythrocytes were washed 3 times with PBS (centrifugation at $1000 \mathrm{rpm}$ for 10 minutes). A $2 \%$ red cell suspension was prepared with PBS. Sample concentrations of 0.5, $0.25,0.1$, and $0.025 \mu \mathrm{g} / \mathrm{mL}$ were incubated with $2 \%$ red cells in PBS in the proportion of $1: 1$ in 96-well plates for 3 hours at $37^{\circ} \mathrm{C} / 5 \% \mathrm{CO}_{2}$. $\mathrm{PBS}$ was used as a negative control, and distilled water was used to control hemolysis. The plates were centrifuged at $1000 \mathrm{rpm}$ for 10 minutes, and supernatants were collected and analyzed for absorbance reading at $550 \mathrm{~nm}$. This experiment was performed in duplicate and repeated three times.

2.16. Statistical Analysis. All of the experiments were performed in triplicate, and the results were expressed as standard error of the mean (SEM) to leishmanicidal analysis and as the mean \pm standard deviation (SD) to other analyses. Results were contrasted with a negative and a positive control. The differences between the values were examined using analysis of variance (ANOVA) followed by Tukey's test for multiple comparisons and a $p$ value $<0.05$ was considered to be statistically significant. Data were analyzed in GraphPad Prism 6.01 software for Windows (GraphPad Software, San Diego, California, USA).

\section{Results and Discussion}

In the recent decades, development of synthetic drugs caused disaffection towards natural products as an attractive resource for searching for new chemotherapy compounds. However, the emergence of some limitations in the use of synthetic drugs as high toxicity, side effects, and elevated costs caused a shift in the situation and interest in the field of ethnobotanical research $[20,25,26]$.

Plant-derived natural products are valuable sources in traditional medicine because they have fewer side effects, low cost, and high availability [27]. Indeed, numerous plantderived bioactive compounds that display a wide variety of pharmacological effects include quercetin and its glucosides rutin and isoquercitrin, common flavonoids, which display antifungal and antileishmanial activities $[16,28,29]$.

The C. coriaceum extracts stand out due to the high antioxidant action of the pulp, which contains carotenoids and phenolic compounds [30]. In phytochemical qualitative screening, the extracts of $C$. coriaceum showed similar constituents for both extracts presenting the secondary metabolites alkaloids, steroids, saponins, tannins, phenols, and flavonoids, in part corroborating with Araruna et al. [31]. Catechins were present only in pulp extract. In phytochemical tests, both extracts showed positive results to flavonoids, which were analyzed by HPLC, and quercetin, rutin, and isoquercitrin were found as main flavonoids present in the extracts.

The fruit peel extract displays a higher amount of phenols, with $55.617 \pm 7.92 \mathrm{mg}$ of gallic acid equivalent $(\mathrm{GAE}) / \mathrm{g}$ of extract (mg GAE/g) and flavonoids with $3.881 \pm 0.10 \mathrm{mg}$ quercetin equivalent $(\mathrm{QE}) / \mathrm{g}$ of extract $(\mathrm{mg} \mathrm{QE} / \mathrm{g})$ when compared with fruit pulp extract which showed $24.539 \pm 3.55$ GAE/g plus $1.334 \pm 0.21 \mathrm{QE} / \mathrm{g}$, as observed in Table 1 .

Quantification of total phenols and flavonoids by spectrophotometry and HPLC analysis for identification of the main flavonoids from these extracts is shown in Table 1. Isoquercitrin bioavailability was shown to be higher than the other two flavonoids. Rutin is present in a lower amount in both extracts and quercetin was present only in the pulp extract.

The presence of active flavonoids in both extracts explains the biological activities found in this study, which was based on in vitro and in silico predictions with natural products [32]. Antioxidants could have a pathogen neutralizing action, directly by scavenging ROS or indirectly by activating pathways that promote ROS degradation [27].

Table 2 displays the results of the extracts and respective standard substances' biological activities, as antioxidant, AChE inhibition, and antifungal. The potential of the pulp extract and peel extracts to inhibit free radicals was evaluated. Radical inhibition was higher with increasing concentration of the extracts when compared to the standard (rutin). Comparing C. coriaceum fruit part extracts, the pulp presented significantly higher antioxidant potential. Regarding the capacity of scavenging free radicals of the extracts, pulp and peel of C. coriaceum fruit showed a better action than that obtained in other plant extracts reported by Moura et al. [33], Penido et al. [20], and Morais et al. [10].

Other studies connected antioxidant mechanisms of action with in vitro fungicidal activities of natural compounds [14]. By Holetz's antimicrobial activity index [25], all the extracts can be classified as good antifungals. The ethanol extracts of C. coriaceum fruit were effective against six animal pathogenic strains: three of the genus Malassezia sp. and three strains of M. canis. The MIC and MFC varied between 39.1 and 4.1 in tested microorganisms' strains. However, all the extracts have better results, when compared to other extracts or isolated compounds elsewhere $[7,8]$.

Against M. canis, the tested extracts obtained better results. Peel extract exhibits greater results than pulp extract that was also considered with high activity. Against Malassezia spp., both extracts exhibit the same MFC and peel extract demonstrates better MIC than pulp extract (Table 2).

With regard to antiacetylcholinesterase activities, the inhibition zone of pulp was greater than peel extract and similar to the control, physostigmine, which means good AChE inhibition. Other studies [16] determined that the isolated flavonoids found and quantified in this study have a remarkable antiacetylcholinesterase activity and indicate this assay as appropriate to antileishmanial studies. This result indicates that probably there is a direct relationship between inhibition of acetylcholinesterase and antileishmanial action.

Regarding leishmaniasis, the interaction between parasites and host immune cells leads to an inflammatory 
TABLE 1: Quantification of total phenols and flavonoids by spectrophotometry and main flavonoids by high-performance liquid chromatography (HPLC) of Caryocar coriaceum fruit ethanol extracts.

\begin{tabular}{|c|c|c|c|c|c|}
\hline Samples & $\begin{array}{l}\text { Total phenols } \\
\text { (mg GAE/g) }\end{array}$ & $\begin{array}{l}\text { Total flavonoids } \\
\quad(\mathrm{mg} \mathrm{QE} / \mathrm{g})\end{array}$ & Quercetin & Rutin & Isoquercetin \\
\hline Pulp extract & $24.539^{\mathrm{b}} \pm 3.55$ & $1.334 \pm 0.21^{\mathrm{b}}$ & $1.965^{\mathrm{a}}$ & $5.025^{\mathrm{a}}$ & $47.665^{\mathrm{b}}$ \\
\hline Peel extract & $55.617^{\mathrm{a}} \pm 7.92$ & $3.881 \pm 0.10^{\mathrm{a}}$ & - & $4.169^{\mathrm{b}}$ & $129.198^{\mathrm{a}}$ \\
\hline
\end{tabular}

Similar small letters indicate significant similarities between rows ( $p<0.0001$, according to ANOVA followed by Tukey's test). - : no result.

TABLE 2: Biological activities of C. coriaceum extracts.

\begin{tabular}{lcccc}
\hline Extracts & $\begin{array}{c}\text { Antioxidant } \\
\text { activity } \\
\left(\mathrm{IC}_{50} \mu \mathrm{g} / \mathrm{mL}\right)\end{array}$ & AChE inhibition $(\mathrm{mm})$ & $\begin{array}{c}\text { Antifungal assay } \\
\text { Malassezia spp. } \\
\text { MFC/MIC }\end{array}$ & $\begin{array}{c}\text { Antifungal assay } \\
\text { Microsporum canis } \\
\text { MFC/MIC }\end{array}$ \\
\hline Pulp & $49.4 \pm 0.29^{\mathrm{c}}$ & $9.0^{\mathrm{a}}$ & $39.06 \pm 1.7^{\mathrm{c}} / 19.53 \pm 1.08^{\mathrm{b}}$ & $9.77 \pm 0.12^{\mathrm{b}} / 4.88 \pm 0.09^{\mathrm{a}}$ \\
Peel & $25.5 \pm 0.26^{\mathrm{b}}$ & $8.5^{\mathrm{b}}$ & $39.06 \pm 0.18^{\mathrm{c}} / 9.77 \pm 0.03^{\mathrm{a}}$ & $4.88 \pm 0.06^{\mathrm{a}} / 4.88 \pm 0.03^{\mathrm{a}}$ \\
Rutin & $13.7 \pm 0.25^{\mathrm{a}}$ & - & - & - \\
Physostigmine & - & $9.0^{\mathrm{a}}$ & - & - \\
\hline
\end{tabular}

Similar letters indicate significant similarities between rows ( $p<0.05$, according to ANOVA followed by Tukey's test). For MFC/MIC assays, similar letters indicate significant similarities between rows ( $p<0.0001$, according to ANOVA followed by Tukey's test). Rutin: positive control to antioxidant activity. Physostigmine: positive control to AChE inhibition. - : not performed.

TABLE 3: Inhibitory concentration of Caryocar coriaceum fruit extracts on promastigote forms of L. amazonensis ( $\left.\mathrm{IC}_{50}\right)$ after 24,48 , and $72 \mathrm{~h}$ of treatment, toxicity to peritoneal macrophages $\left(\mathrm{CC}_{50}\right)$, and selectivity index $(\mathrm{SI})$ after $24 \mathrm{~h}$ of treatment. Values are expressed in $\mu \mathrm{g} / \mathrm{mL}$.

\begin{tabular}{|c|c|c|c|c|c|}
\hline & $\begin{array}{l}24 \mathrm{~h} \\
\mathrm{IC}_{50}\end{array}$ & $\mathrm{CC}_{50}$ & SI & $\begin{array}{l}48 \mathrm{~h} \\
\mathrm{IC}_{50} \\
\end{array}$ & $\begin{array}{l}72 \mathrm{~h} \\
\mathrm{IC}_{50}\end{array}$ \\
\hline Pulp extract & $30 \pm 5.0^{\mathrm{a}}$ & $253 \pm 42.0^{\mathrm{b}}$ & $8.43^{\mathrm{b}}$ & $39 \pm 8.0$ & $17 \pm 7.0$ \\
\hline Peel extract & $38 \pm 13.0^{\mathrm{a}}$ & $454 \pm 11.0^{\mathrm{a}}$ & $11.94^{\mathrm{a}}$ & $31 \pm 9.0$ & $22 \pm 3.0$ \\
\hline Pentamidine [9] & $23.71^{\mathrm{a}}(18.44-30.50)$ & $17.90^{c}(0.02-0.03)$ & $0.75^{\mathrm{c}}$ & & \\
\hline Glucantime [17] & $13.95( \pm 2.06)^{\mathrm{a}}$ & & & & \\
\hline
\end{tabular}

Data represent the mean \pm SEM of at least three independent experiments performed in triplicate. $\mathrm{CC}_{50}$ : cytotoxic concentration of $50 \%$ of macrophages $(\mu \mathrm{g} / \mathrm{mL})$. $\mathrm{IC}_{50}$ : inhibitory concentration of $50 \%$ of promastigote forms $(\mu \mathrm{g} / \mathrm{mL})$. SI: selectivity index $=\mathrm{CC}_{50} / \mathrm{IC}_{50}$. Similar letters indicate significant similarities between rows ( $p \leq 0.05$, according to ANOVA followed by Tukey's test).

response essential for parasite control. However, an exacerbated proinflammatory response may cause tissue damage, resulting in lesion formation observed in cutaneous leishmaniasis [34, 35]. On the other hand, the lack of an effective inflammatory response may promote increased parasite burden [26]. In this scenario, the antioxidant effect of C. coriaceum extracts can control the inflammatory response being ideal for an effective control of the disease.

Table 3 displays the inhibitory concentration of Caryocar coriaceum fruit extracts on promastigote forms of L. amazonensis $\left(\mathrm{IC}_{50}\right)$ after 3 days of treatment, toxicity to peritoneal macrophages $\left(\mathrm{CC}_{50}\right)$, and selectivity index (SI) after $24 \mathrm{~h}$ of treatment. $\mathrm{IC}_{50}$ in parasite proliferation was shown to be similar after $24 \mathrm{~h}$ of treatment for both extracts and the standards. At $48 \mathrm{~h}$, there was yet no statistical difference between the treatments. A dose-dependent reaction was found after $72 \mathrm{~h}$ with $\mathrm{IC}_{50}$ results reduced.

To test the selectivity of pulp and peel extracts, murine macrophages were treated with different concentrations of extracts and the viability of these cells was assessed by the MTT reduction. Pulp extract induced 50 percent of cytotoxicological effect $\left(\mathrm{CC}_{50}\right)$ in peritoneal macrophages at lower concentration than peel at $24 \mathrm{~h}$, but both extracts presented statistically the lowest toxicity compared to the standard (pentamidine). In addition, pulp extract presented a good predilection of the extract by the parasites, being better selective than pentamidine. Then, the $C$. coriaceum extracts had higher toxicity to $L$. amazonensis promastigote forms and demonstrated lower cytotoxicity on murine macrophages and erythrocytes and statistically better results than demonstrated in previous studies for pentamidine and glucantime as standards $[9,17]$.

Another way to evaluate the cytotoxicity of extracts is by the ability to cause hemolysis in human erythrocytes. As shown in Table 4, the pulp and peel extracts showed low toxicity. The lowest concentration determines hemolytic activities at $0.909 \pm 0.746$ and $0.616 \pm 0.224$ per cent, respectively, though with very low levels of hemolysis. The 
TABLE 4: Hemolytic activity (\%) of Caryocar coriaceum fruit extracts (mg/mL).

\begin{tabular}{lccccc}
\hline & 0.025 & 0.05 & 0.1 & 0.25 & 0.5 \\
\hline Pulp extract & $0.909( \pm 0.746)$ & $1.300( \pm 0.341)$ & $1.295( \pm 0.564)$ & $2.406( \pm 1.206)$ & $8.777( \pm 4.102)$ \\
Peel extract & $0.616( \pm 0.224)$ & $1.229( \pm 0.740)$ & $0.925( \pm 0.315)$ & $3.068( \pm 1.368)$ & $6.872( \pm 3.056)$ \\
\hline
\end{tabular}

Data represent the mean \pm SEM of at least three independent experiments performed in triplicate. Data were normalized to the positive control (distilled water).

C. coriaceum fruit extracts presented low hemolytic activity, and concentrations of $0.1,0.05$, and $0.025 \mu \mathrm{g} / \mathrm{mL}$ were not able to cause significant hemolysis.

\section{Conclusions}

The secondary metabolites produced by C. coriaceum are potentially bioactive substances acting as antifungal and antileishmanial agents, mainly by scavenging free radicals and anticholinesterase mechanisms. The flavonoids quercetin, rutin, and isoquercitrin are important indicators of these activities. The results obtained in this study corroborate the potential of these plant species and may form the basis for new antifungal and antileishmanial agents. Nevertheless, further studies are necessary for the isolation and characterization of other substances and in vivo studies should be performed to detect the bioavailability of these extracts, aiming at the development of possible new pharmaceutical products.

\section{Conflicts of Interest}

All the authors declare that there are no financial/commercial conflicts of interest.

\section{Acknowledgments}

The authors are grateful to the Conselho Nacional de Desenvolvimento Científico e Tecnologico (CNPq) for a fellowship to the first author, to Empresa Brasileira de Pesquisa Agropecuária (EMBRAPA), to Universidade Estadual de Londrina, to Universidade Estadual do Ceará (Núcleo de Pesquisa em Sanidade Animal, NUPESA), and to Vettings for laboratory facilities and supplying drugs and microorganisms.

\section{References}

[1] D. M. Hawkins and A. C. Smidt, "Superficial fungal infections in children," Pediatric Clinics of North America, vol. 61, no. 2, pp. 443-455, 2014.

[2] M. Zahur, A. Afroz, U. Rashid, and S. Khaliq, "Dermatomycoses: challenges and human immune responses," Current Protein and Peptide Science, vol. 15, no. 5, pp. 437-444, 2014.

[3] WHO/Department of Control of Neglected Tropical Diseases, "Leishmaniasis in high-burden countries: an epidemiological update based on data reported in 2014", Weekly Epidemiological Record, vol. 22, no. 91, pp. 285-296, 2016.

[4] R. M. Cardoso, N. N. S. L. de Ara, and G. A. S. Romero, "Expanding the knowledge about Leishmania species in wild mammals and dogs in the Brazilian savannah," Parasites Vectors, vol. 8, no. 1, p. 171, 2015.
[5] M. N. Saridomichelakis and A. F. Koutinas, "Cutaneous involvement in canine leishmaniosis due to Leishmania infantum (syn. L. chagasi)," Veterinary Dermatology, vol. 25, no. 2, pp. 61-e22, 2014.

[6] F. C. M. Rondon, C. M. L. Bevilaqua, M. P. Accioly et al., "In vitro effect of Aloe vera, Coriandrum sativum and Ricinus communis fractions on Leishmania infantum and on murine monocytic cells," Veterinary Parasitology, vol. 178, no. 3-4, pp. 235-240, 2011.

[7] B. V. Soares, S. M. Morais, and R. O. S. Fontenelle, "Antifungal activity of plant extracts against Microsporum canis and Candida spp," Boletín Latinoamericano y del Caribe de Plantas Medicinales y Aromáticas, vol. 14, no. 4, pp. 263-272, 2015.

[8] P. Torabzadeh and P. Panahi, "Evaluation of antifungal activity of Physalis alkekengi L. extracts on Microsporum canis, Candida albicans, Trichophyton mentagrophytes and Nocardia asteroids," Middle East Journal of Scientific Research, vol. 13, no. 7, pp. 926-929, 2013.

[9] A. A. S. Silva, S. M. Morais, M. J. C. Falcão et al., "Activity of cycloartane-type triterpenes and sterols isolated from Musa paradisiaca fruit peel against Leishmania infantum chagasi," Phytomedicine, vol. 21, no. 11, pp. 1419-1423, 2014.

[10] M. L. Morais, A. C. Silva, C. R. Araújo, E. A. Esteves, and N. A. Dessimoni-Pinto, "Determinação do potencial antioxidante in vitro de frutos do Cerrado brasileiro," Revista Brasileira de Fruticultura, vol. 35, no. 2, pp. 355-360, 2013.

[11] L. S. Carvalho, K. F. Pereira, and E. G. Araújo, "Características botânicas, efeitos terapêuticos e princípios ativos presentes no pequi (Caryocar brasiliense)," Arquivos de Ciências da Saúde da UNIPAR, vol. 19, no. 2, pp. 147-157, 2015.

[12] J. Ascari, J. A. Takahashi, and M. A. D. Boaventura, "The phytochemistry and biological aspects of caryocaraceae family," Revista Brasileira de Plantas Medicinais, vol. 15, no. 2, pp. 293308, 2013.

[13] M. L. M. de Oliveira, D. C. S. Nunes-Pinheiro, A. R. Tomé et al., "In vivo topical anti-inflammatory and wound healing activities of the fixed oil of Caryocar coriaceum Wittm. seeds," Journal of Ethnopharmacology, vol. 129, no. 2, pp. 214-219, 2010.

[14] W. d. Paula-Ju, F. H. Rocha, L. Donatti, C. M. Fadel-Picheth, and A. M. Weffort-Santos, "Leishmanicidal, antibacterial, and antioxidant activities of Caryocar brasiliense Cambess leaves hydroethanolic extract," Revista Brasileira de Farmacognosia, vol. 16, pp. 625-630, 2006.

[15] X. S. Passos, S. Da Costa Santos, P. H. Ferri et al., "Antifungal activity of Caryocar brasiliensis (caryocaraceae) against Cryptococcus neoformans," Revista da Sociedade Brasileira de Medicina Tropical, vol. 35, no. 6, pp. 623-627, 2002.

[16] N. S. Vila-Nova, S. M. Morais, M. J. C. Falcão et al., "Leishmanicidal and cholinesterase inhibiting activities of phenolic compounds of Dimorphandra gardneriana and Platymiscium floribundum, native plants from Caatinga biome," Pesquisa Veterinaria Brasileira, vol. 32, no. 11, pp. 1164-1168, 2012.

[17] A. A. S. Silva, J. de, B. Alexandre, and L. G. Vieira, "Estudo fitoquímico e atividades leishmanicida, anticolinestarásica e 
antioxidante de extratos de Annona glabraL. (araticum panã)," Journal of Applied Pharmaceutical Science, vol. 36, no. 2, pp. 189194, 2015.

[18] C. M. Sousa, H. R. Silva, G. M. Jr. Vieira et al., "Fenóis totais e atividade antioxidante de cinco plantas medicinais," Química Nova, vol. 30, no. 2, pp. 351-355, 2007.

[19] C. S. Funari and V. O. Ferro, "Análise de própolis," Ciencia e Tecnologia de Alimentos, vol. 26, no. 1, pp. 171-178, 2006.

[20] A. B. Penido, S. M. De Morais, A. B. Ribeiro et al., "Medicinal plants from northeastern Brazil against alzheimer's disease," Evidence-Based Complementary and Alternative Medicine, vol. 2017, pp. 1-7, 2017.

[21] G. L. Ellman, K. D. Courtney, V. Andres Jr., and R. M. Featherstone, "A new and rapid colorimetric determination of acetylcholinesterase activity," Biochemical Pharmacology, vol. 7, no. 2, pp. 88-95, 1961.

[22] I. K. Rhee, M. van de Meent, K. Ingkaninan, and R. Verpoorte, "Screening for acetylcholinesterase inhibitors from Amaryllidaceae using silica gel thin-layer chromatography in combination with bioactivity staining," Journal of Chromatography A, vol. 915, no. 1-2, pp. 217-223, 2001.

[23] 3nd ed Clinical and Laboratory Standards Institute, Clinical and Laboratory Standards Institute (CLSI) Reference Method for Broth Dilution Antifungal Sucscetibility Testing of Yeasts Approved Standard M27-A3. Wayne, Pensilvanya, 2008.

[24] T. Mosmann, "Rapid colorimetric assay for cellular growth and survival: application to proliferation and cytotoxicity assays," Journal of Immunological Methods, vol. 65, no. 1-2, pp. 55-63, 1983.

[25] F. B. Holetz, G. L. Pessini, N. R. Sanches, D. A. G. Cortez, C. V. Nakamura, and B. P. Dias Filho, "Screening of some plants used in the Brazilian folk medicine for the treatment of infectious diseases," Memorias do Instituto Oswaldo Cruz, vol. 97, no. 7, pp. 1027-1031, 2002.

[26] I. A. Rodrigues, A. M. Mazotto, V. Cardoso et al., "Natural products: insights into leishmaniasis inflammatory response," Mediators of Inflammation, vol. 2015, Article ID 835910, 12 pages, 2015.

[27] L. G. Rocha, J. R. G. S. Almeida, R. O. Macêdo, and J. M. Barbosa-Filho, "A review of natural products with antileishmanial activity," Phytomedicine, vol. 12, no. 6-7, pp. 514-535, 2005.

[28] D. G. Valadares, M. C. Duarte, J. S. Oliveira et al., "Leishmanicidal activity of the Agaricus blazei Murill in different Leishmania species," Parasitology International, vol. 60, no. 4, pp. 357-363, 2011.

[29] A. M. Metwally, A. A. Omar, F. M. Harraz, and S. M. El Sohafy, "Phytochemical investigation and antimicrobial activity of Psidium guajava L. leaves," Pharmacognosy Magazine, vol. 6, no. 23, pp. 212-218, 2010.

[30] R. Roesler, L. C. Carrasco, and R. B. Holanda, "Antioxidant activity of cerrado fruits," Ciência e Tecnologia de Alimentos, vol. 27, no. 1, pp. 53-60, 2007.

[31] M. K. A. Araruna, K. K. A. Santos, J. G. M. Da Costa et al., "Phenolic composition and in vitro activity of the Brazilian fruit tree Caryocar coriaceum Wittm.," European Journal of Integrative Medicine, vol. 5, no. 2, pp. 178-183, 2013.

[32] A. C. F. Salgueiro, V. Folmer, H. S. da Rosa et al., "In vitro and in silico antioxidant and toxicological activities of Achyrocline satureioides," Journal of Ethnopharmacology, vol. 194, pp. 6-14, 2016.
[33] L. R. Moura, A. C. Martins, L. A. Vaz et al., "Extrato hidroalcoolico da casca do pequi (Caryocar brasiliense) em ratos submetidos à aplicação de doxorrubicina," Ciência Rural, vol. 43, no. 1, pp. 100-106, 2013.

[34] C. da Silva Santos, S. Attarha, R. K. Saini et al., "Proteome profiling of human cutaneous leishmaniasis lesion," The Journal of Investigative Dermatology, vol. 135, no. 2, pp. 400-410, 2014.

[35] C. D. S. Santos, V. Boaventura, C. Ribeiro Cardoso et al., "CD8 ${ }^{+}$ granzyme $\mathrm{B}^{+}$-mediated tissue injury vs. $\mathrm{CD} 4^{+} \mathrm{IFN} \gamma^{+}$-mediated parasite killing in human cutaneous leishmaniasis," Journal of Investigative Dermatology, vol. 133, no. 6, pp. 1533-1540, 2013. 


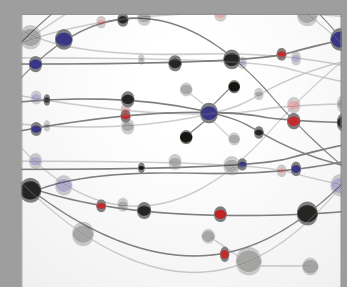

The Scientific World Journal
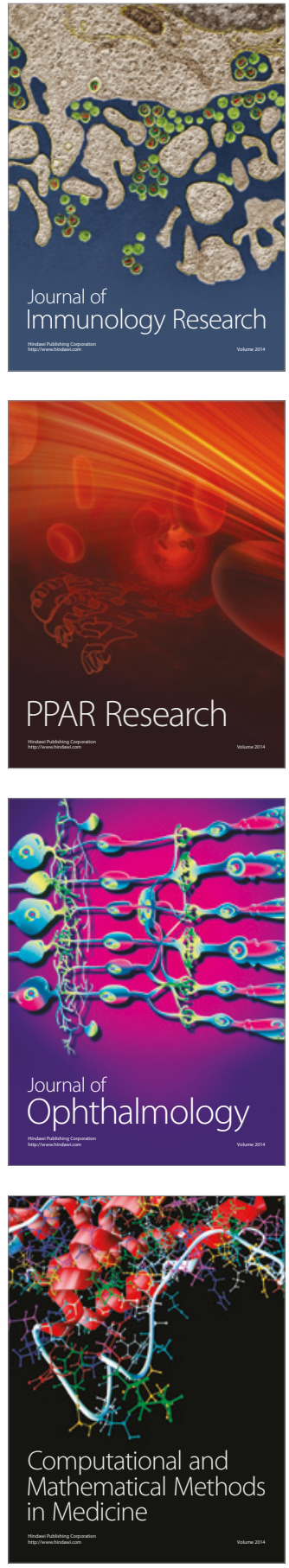

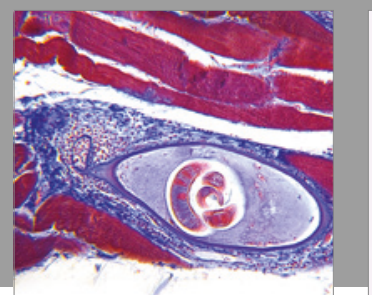

Gastroenterology Research and Practice
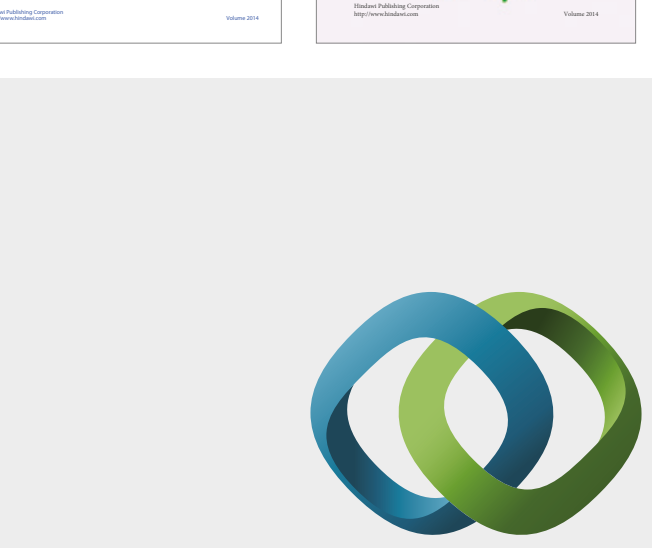

\section{Hindawi}

Submit your manuscripts at

https://www.hindawi.com
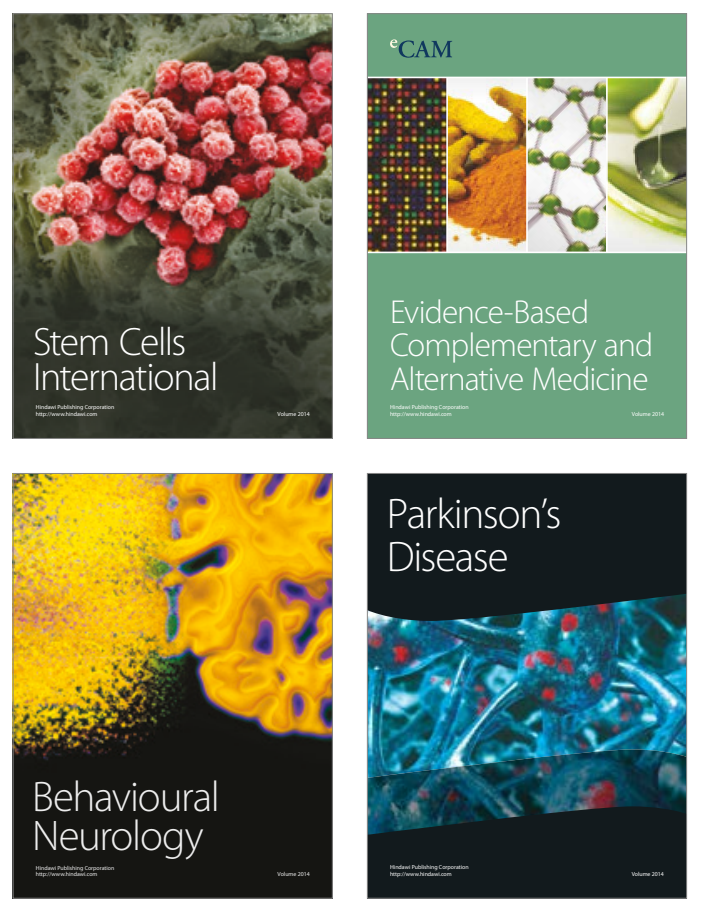
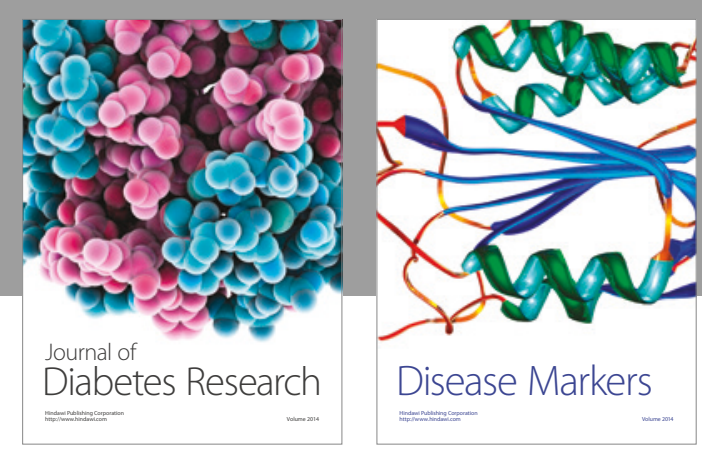

Disease Markers
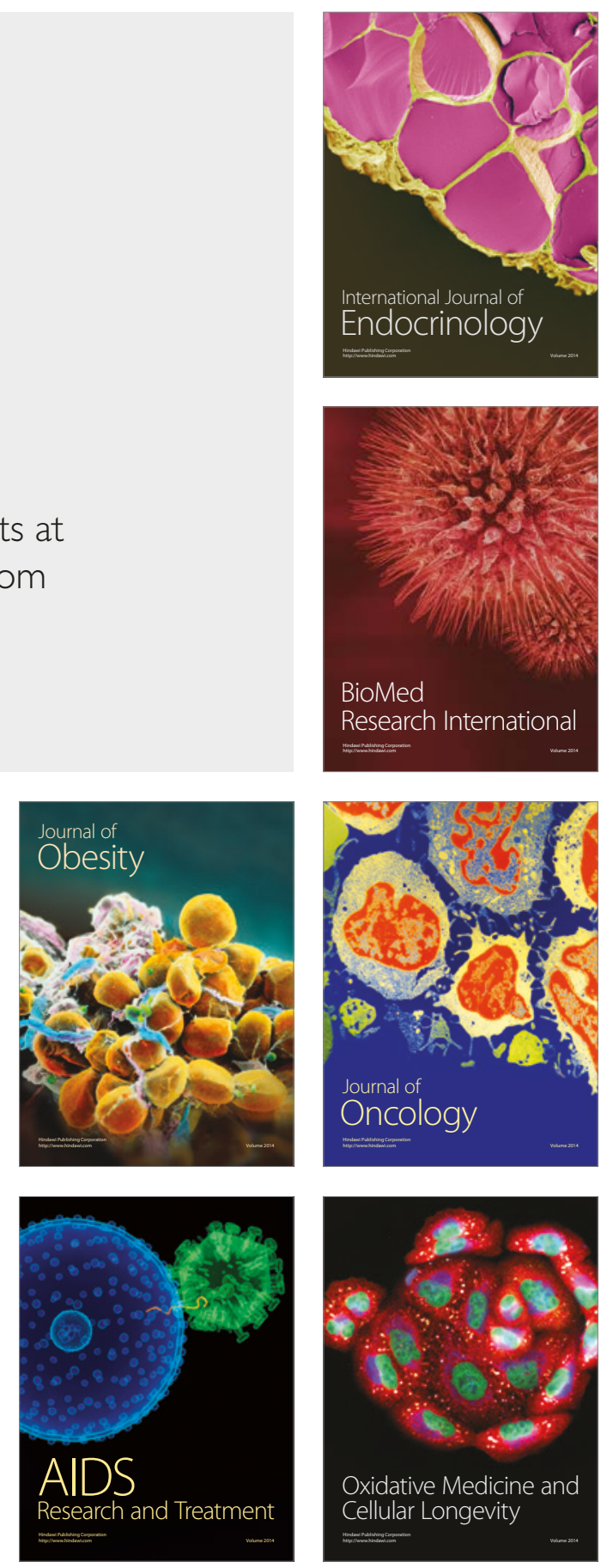